\title{
Elevation of the Gangdese Mountains and Their Impacts on Asian Climate During the Late Cretaceous - a Modeling Study
}

\author{
Jian Zhang ${ }^{1,2,3 *}$, Yonggang Liu $^{3}$, Xiaomin Fang ${ }^{1,2 *}$, Tao Zhang ${ }^{1,4}$, Chenguang Zhu ${ }^{5,6}$ and \\ Chengshan Wang ${ }^{5}$
}

${ }^{1}$ State Key Laboratory of Tibetan Plateau Earth System, Resources and Environment (TPESRE), Institute of Tibetan Plateau Research, Chinese Academy of Sciences, Beijing, China, ${ }^{2}$ Key Laboratory of Continental Collision and Plateau Uplift, Institute of Tibetan Plateau Research, Chinese Academy of Sciences, Beijing, China, ${ }^{3}$ Department of Atmosphere and Ocean Sciences, School of Physics, Peking University, Beijing, China, ${ }^{4}$ School of Earth Sciences and Key Laboratory of Western China's Mineral Resources of Gansu Province, Lanzhou University, Lanzhou, China, ${ }^{5}$ State Key Laboratory of Biogeology and Environmental Geology, School of Earth Sciences and Resources, China University of Geosciences, Beijing, China, ${ }^{6}$ School of Environmental Studies, China University of Geosciences, Wuhan, China

OPEN ACCESS

Edited by:

Shiming Wan,

Institute of Oceanology (CAS), China

Reviewed by:

Fangyang $\mathrm{Hu}$,

Institute of Geology and Geophysics

(CAS), China

Ran Zhang,

Institute of Atmospheric Physics

(CAS), China

*Correspondence: Jian Zhang jzhangcn@126.com

Xiaomin Fang

fangxm@itpcas.ac.cn

Specialty section:

This article was submitted to Structural Geology and Tectonics, a section of the journal

Frontiers in Earth Science

Received: 08 November 2021 Accepted: 30 November 2021

Published: 16 December 2021

Citation:

Zhang J, Liu Y, Fang X, Zhang T, Zhu C and Wang $C$ (2021) Elevation of the

Gangdese Mountains and Their Impacts on Asian Climate During the Late Cretaceous - a Modeling Study. Front. Earth Sci. 9:810931. doi: 10.3389/feart.2021.810931
Uplift of the Gangdese Mountains is important to the evolution of Asian monsoons and the formation of Tibetan Plateau, but its paleoaltitude before the India-Asia collision (Late Cretaceous) is less constrained so far. In this study, we investigate whether the geological records, which are indicators of soil dryness, discovered in East Asia can provide such a constraint. Through climate modeling using the Community Earth System Model version 1.2.2, it is found that the extent of dry land in East Asia is sensitive to the altitude of the Gangdese Mountains. It expands eastwards and southwards with the rise of the mountain range. Comparison of the model results with all the available geological records in this region suggests that the Gangdese Mountains had attained a height of $\sim 2 \mathrm{~km}$ in the Late Cretaceous.

Keywords: Gangdese Mountains, Tibetan Plateau, tectonic uplift, asian climate, Late Cretaceous, paleoclimate modeling

\section{INTRODUCTION}

The Tibetan Plateau (TP) topography started to form due to crustal thickening and surface uplift in the northern margin of the Lhasa terrane (Murphy et al., 1997; Kapp et al., 2007; Leier et al., 2007) when it collided with the Qiangtang terrane during the latest Jurassic to Early Cretaceous (Dewey et al., 1988). Then the northward subduction of the Neotethyan oceanic lithosphere formed an Andean-type continental margin along the southern paleo-Asia, leading to the uplift of the Gangdese Mountains (England and Searle, 1986). Based on the geological and geochronological results, early work suggested that the Gangdese Mountains might have risen to $3,4 \mathrm{~km}$ elevation just before or around the India-Asia collision ( $55 \pm 10$ Ma; Najman et al., 2010; Wu et al., 2014; Hu et al., 2015), due to either the north-south shortening of the Lhasa block or the subduction of the Neotethyan oceanic lithosphere (Murphy et al., 1997; Kapp et al., 2003; Kapp et al., 2005). More recently, based on the values of oxygen isotope $\left(\delta^{18} \mathrm{O}\right)$, Ding et al. (2014) proposed that the Gangdese Mountains had reached $4.5 \pm 0.4 \mathrm{~km}$ at $\sim 56 \mathrm{Ma}$, consistent with the earlier results. However, quantitative construction of the paleoelevation of the Gangdese Mountains before the India-Asia collision, such as Late Cretaceous, is very rare. Zhu et al. (2017) obtained a crustal thickness of $\sim 30-70 \mathrm{~km}$ 
during the Late Cretaceous for the Gangdese arc based on the compiled $\mathrm{La} / \mathrm{Yb}$ ratios, from which a wide range from less than $1 \mathrm{~km}$ to greater than $5 \mathrm{~km}$ was estimated for the elevation of the Gangdese Mountains. With an improved method that does not require making assumptions for the variation of crustal and/or mantle densities, Hu et al. (2020) concluded that the Gangdese arc was $\sim 2.5 \mathrm{~km}$ high, but decreased to $\sim 2 \mathrm{~km}$ at $\sim 75 \mathrm{Ma}$.

Knowing the altitude of the Gangdese Mountains is important for understanding the tectonic and geodynamic processes involved in the interaction between tectonic plates during the Cretaceous ( 144-66 Ma) and Cenozoic ( 66-0 Ma; Tapponnier et al., 2001; Ding and Lai, 2003; DeCelles et al., 2007; Wang et al., 2008; Ding et al., 2014; Wang et al., 2014a; Sun et al., 2015). It is also important for us to understand the evolution of Asian monsoon, since it has been demonstrated that the presence of a mountain range such as the Himalaya alone can sustain the major characteristics of the present-day Asian monsoons (Boos and Kuang, 2010; Acosta and Huber, 2020). Recently, Farnsworth et al. (2019) also demonstrated that the past East Asian monsoon evolution is mainly controlled by paleogeography. That means that the Gangdese Mountains, if high enough, should have already had an impact on the Asian climate during the Cretaceous (Qiu, 2014). Therefore, a constraint on the paleoaltitude of this mountain range is needed.

Previous studies have shown that the TP-Himalaya has a crucial impact on the Asian climate (An et al., 2001; Zhang et al., 2007; Zhang et al., 2015; Zhang et al., 2018a; Zhu et al., 2019), especially the Asian summer monsoon (Yeh and Chang, 1974; Hahn and Manabe, 1975; Boos and Kuang, 2010; Wu et al., 2012b); it also dries the region to the north (Kutzbach et al., 1993; Wu et al., 2012a). The insulation effects and thermal forcings of the Gangdese Mountains were probably similar to those of the TP-Himalaya that uplifted later (Wang et al., 2008) since they locate at similar latitudes. The climate impact of the TP-Himalaya has been well studied (Boos and Kuang, 2010; Ma et al., 2014; Acosta and Huber, 2020) and it has been known that the magnitude of impact is sensitive to the altitude of TP (Liu and Yin, 2002; Kitoh, 2004). This sensitivity has been used to constrain the paleoelevation of $\mathrm{TP}$ during Eocene by comparing the simulation results with the isotope records, i.e. $\delta^{18} \mathrm{O}$ (Botsyun et al., 2019). Although the results of their study were questioned due to the shortcomings of isotope modeling in climate models (Valdes et al., 2019), it provided a potentially useful alternative way of reconstructing paleoelevation. If the climate over surrounding regions is similarly sensitive to the paleoaltitude of the Gangdese Mountains, then we may be able to provide a constraint on its paleoaltitude during the Late Cretaceous by comparing climate modeling results to available climate reconstructions. Such method has also been used to infer the paleoaltitude of the Appalachian and Variscan ranges during the late Permian (Fluteau et al., 2001). In that work, the reconstructed distribution of aridity/wetness was used as indicators of climate.

During the Late Cretaceous (more specifically, $\sim 85-66 \mathrm{Ma}$ is the time period we focus here), an arid/semi-arid climate in the low-to mid-latitude Asia is indicated by widespread eolian and red bed deposits (Jiang et al., 2004; Jiang et al., 2008; Hasegawa et al., 2012), while humid climate in the mid-to high-latitude Asia was indicated by floras, coal-bearing strata and oil shale deposits (Spicer and Herman, 2010; Wang et al., 2013). Such dry/wet information may be used to broadly constrain the height of the Gangdese Mountains. To test whether this will work, a series of modeling experiments in which the Gangdese Mountains are prescribed at different altitudes have been carried out. The impacts of the Gangdese Mountains on Asian climate and a possible constraint on the paleoaltitude of the Gangdese Mountains are, therefore, obtained at the same time.

\section{MODEL AND EXPERIMENTAL DESIGN}

In this study, the Community Earth System Model version 1.2.2 (CESM1.2.2) developed by National Center for Atmospheric Research (NCAR) is employed. CESM1.2.2 is a general circulation model including seven components: atmosphere (CAM4), ocean (POP2), land (CLM4), river runoff (ROF), sea ice (CICE4), land ice, and ocean wave, which interact with each other through a coupler (Vertenstein et al., 2013). For the purpose of the present study, the last two components are not turned on. In order to resolve the Gangdese Mountains in the model, relatively high spatial resolution (e.g. $1^{\circ}$ in the horizontal direction) is required. However, the computational cost of running the fully coupled model (with the first five components active) at such a high resolution to equilibrium is formidable. Therefore, we take the strategy by first obtaining the sea surface temperatures (SSTs) and sea ice distributions using the fully coupled model at low resolution. Then the sensitivity of Asian climate to the height of the Gangdese Mountains is tested with the high-resolution atmosphere model (CAM4 and CLM4), with the SSTs and sea ice fractions prescribed to those obtained from the low-resolution fully coupled model.

In the fully coupled experiment (CoupExp), the geography of $\sim 75 \mathrm{Ma}$ (Figure 1A) modified from Scotese and Wright (2018) and paleovegetation (Figure 1B) interpolated from Sewall et al. (2007) are implemented. In CoupExp, CAM4 is run at a horizontal resolution of $\mathrm{T} 31\left(3.75^{\circ} \times 3.75^{\circ}\right)$ with 26 levels in the vertical. CLM4 is run at the same horizontal resolution as that of CAM4. POP2 employs a gx3v7 grid which has 116 and 100 grid points in the meridional and zonal directions, respectively, and 60 levels in the vertical. CICE4 is run on the same horizontal grid as POP2. ROF with the default resolution $\left(0.5^{\circ} \times 0.5^{\circ}\right)$ routes all runoff to the oceans. In order to simulate the climatic effects of the Gangdese Mountains, five sensitivity experiments (i.e. Gds_0 km, Gds_1 km, Gds_2 km, Gds_3 km, and Gds_4 km) in total are carried out with the high-resolution $\left(1.25^{\circ}\right.$ in longitude and $0.9^{\circ}$ in latitude) atmospheric model. The topography in experiment Gds_ $0 \mathrm{~km}$ is the same as that in CoupExp, i.e. the topography along the south margin of the paleo-Asia is only less than $300 \mathrm{~m}$ high (Figure 1A). In the other four experiments, everything is the same as that in $\mathrm{Gds} \_0 \mathrm{~km}$ except that the altitude of Gangdese Mountains along the south margin of the paleo-Asian continent is varied from 1 to $4 \mathrm{~km}$ with a step of $1 \mathrm{~km}$ (Figures $2 \mathrm{~A}-\mathbf{D}$ ). In these four experiments, the Gangdese Mountains are assumed to extend from approximately 

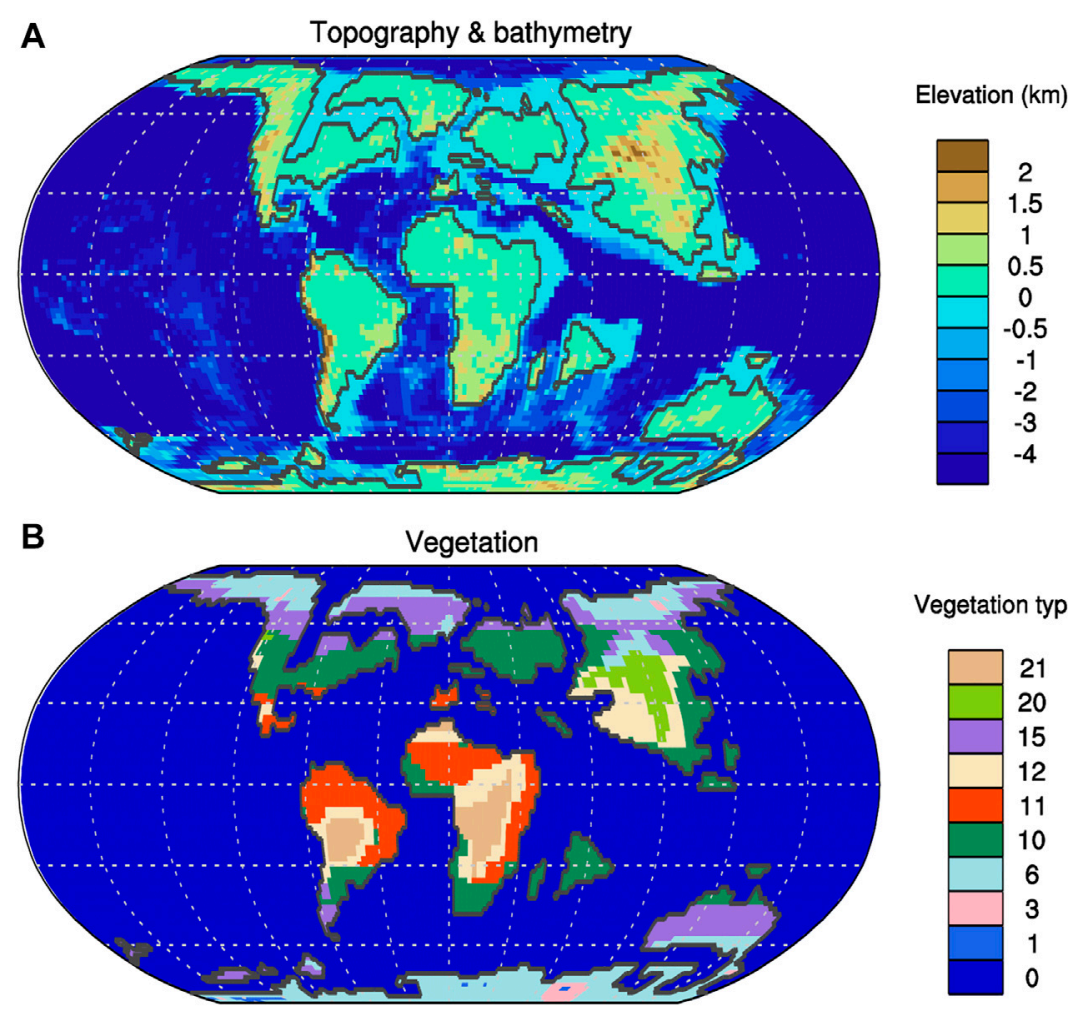

FIGURE 1 | Paleogeography (A) of 75 Ma modified from Scotese and Wright (2018) and the corresponding paleovegetation (B) interpolated from Sewall et al. (2007). In (B), the numbers 0 is for the ocean, 1 for the land ice, 3 for the high altitude/latitude evergreen conifer closed canopy forest, 6 for the high altitude/latitude mixed forest with equal percentage broad vs needle leaf and evergreen vs deciduous, 10 for the closed canopy, broad leaved, moist evergreen forest, 11 for the closed canopy, broad leaved, dry deciduous forest, 12 for the savanna (dry, low understory with sparse broad leaved overstory), 15 for the high altitude/latitude moist, open canopy evergreen forest with shrub understory, 20 for the wet or cool shrubland (evergreen), and 21 for the dry or warm shrubland (deciduous), which is the same as the Land Surface Model (LSM) vegetation types.
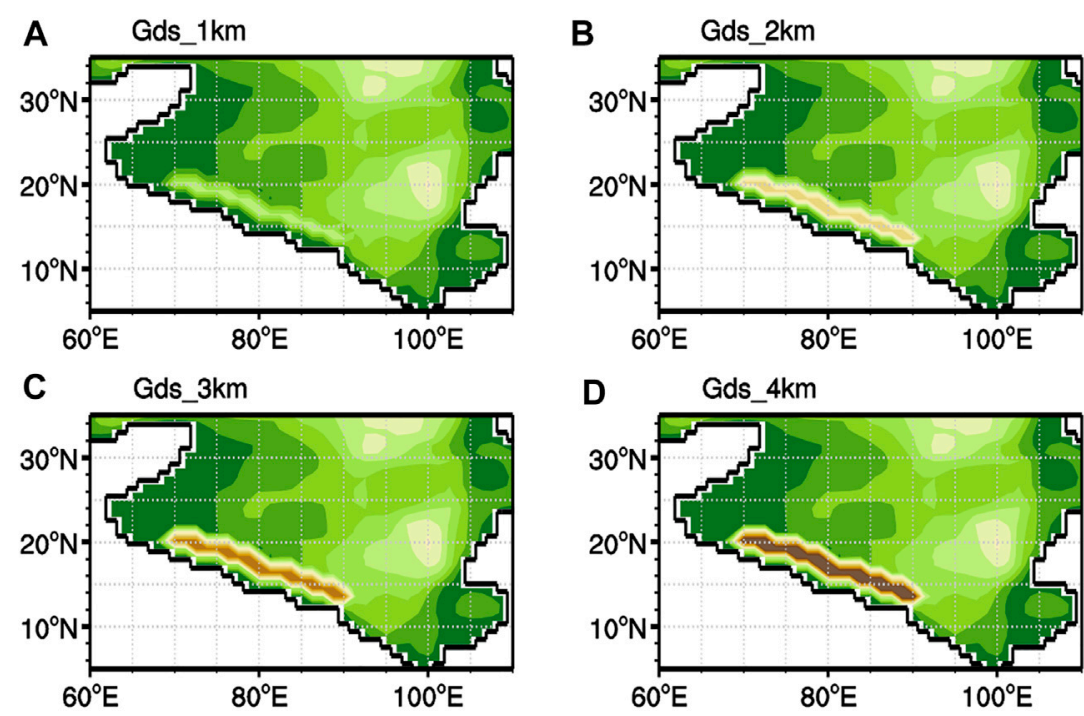

D Gds_4km

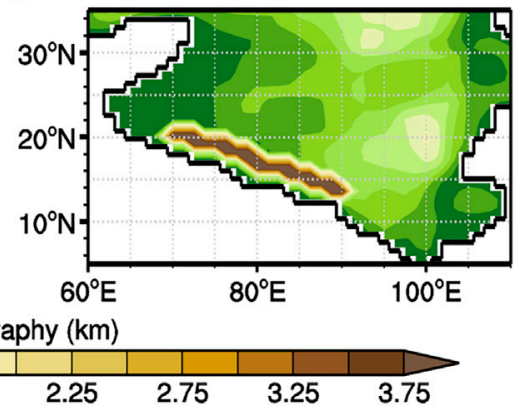

FIGURE 2 | The altitude of the Gangdese Mountains for the experiments Gds_1 km (A), Gds_2 km (B), Gds_3 km (C) and Gds_4 km (D). 
TABLE 1 | Description of the experimental setup.

\section{CoupExp}

Gds_O km

Gds_1 km

Gds_2 km

Gds 3 km

Gds_4 km
The fully coupled experiment at a low resolution of T31_g37

The atmospheric experiment at a high resolution $\left(1.25^{\circ} \times 0.9^{\circ}\right)$, the topography is the same as that in CoupExp (Figure 1A)

Same as the experiment Gds_0 km, but the Gangdese Mountains of $1 \mathrm{~km}$ are included (Figure 2A)

Same as the experiment Gds_0 km, but the Gangdese Mountains of $2 \mathrm{~km}$ are included (Figure 2B)

Same as the experiment Gds_0 km, but the Gangdese Mountains of $3 \mathrm{~km}$ are included (Figure 2C)

Same as the experiment Gds_0 km, but the Gangdese Mountains of $4 \mathrm{~km}$ are included (Figure 2D)
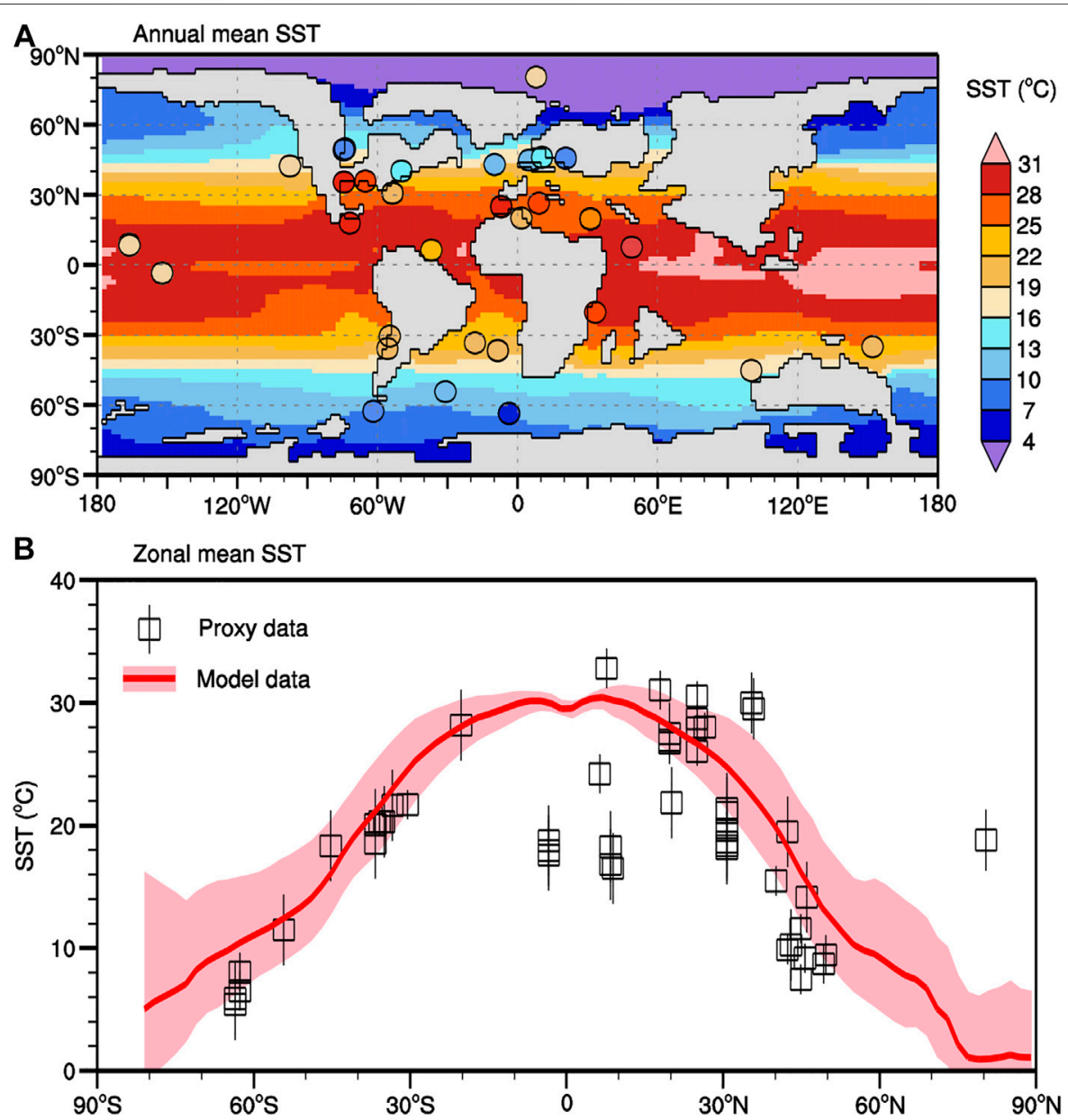

FIGURE 3 | Comparison of the annual-mean SST between model simulations (this study) and proxy data (Tabor et al., 2016). The proxy data are shown as filled circles in (A) and blank squares in (B) where the overlying vertical lines represent their uncertainties. In (B), the zonal mean SST from the model is calculated and indicated by the red lines, with the pink shading represents the simulated range of the monthly climatology.

$70-90^{\circ}$ E along the south margin of the Paleo-Asian continent; this latitudinal position is consistent with the paleoaltitude reconstruction (Liebke et al., 2010; Tan et al., 2010). All experiments are summarized in Table $\mathbf{1 .}$

The atmospheric $\mathrm{CO}_{2}$ concentration during the Late Cretaceous is poorly constrained and might have varied within a large range (Wang et al., 2014b). Fortunately, the aridity over Asia has been shown to have a low sensitivity to $\mathrm{CO}_{2}$ level (Farnsworth et al., 2019; Zhang et al., 2019). Therefore, in all experiments carried out herein, the $\mathrm{CO}_{2}$ concentration is set to twice its pre-industrial level, i.e. 560 ppmv, which is within the range of the proxy reconstructions (Wang et al., 2014b). The concentrations of all other gases and aerosols, including $\mathrm{CH}_{4}$, $\mathrm{N}_{2} \mathrm{O}$, and $\mathrm{O}_{3}$, are set to the pre-industrial level, i.e. the default values of the CESM1.2.2. The concentrations of CFCs are set to 0 . Though orbital configuration has a great influence on the Asian climate in Cretaceous (Jiang et al., 2004; Zhang et al., 2019), these timescales $(<0.1$ million years) are much shorter than that $(1$ 

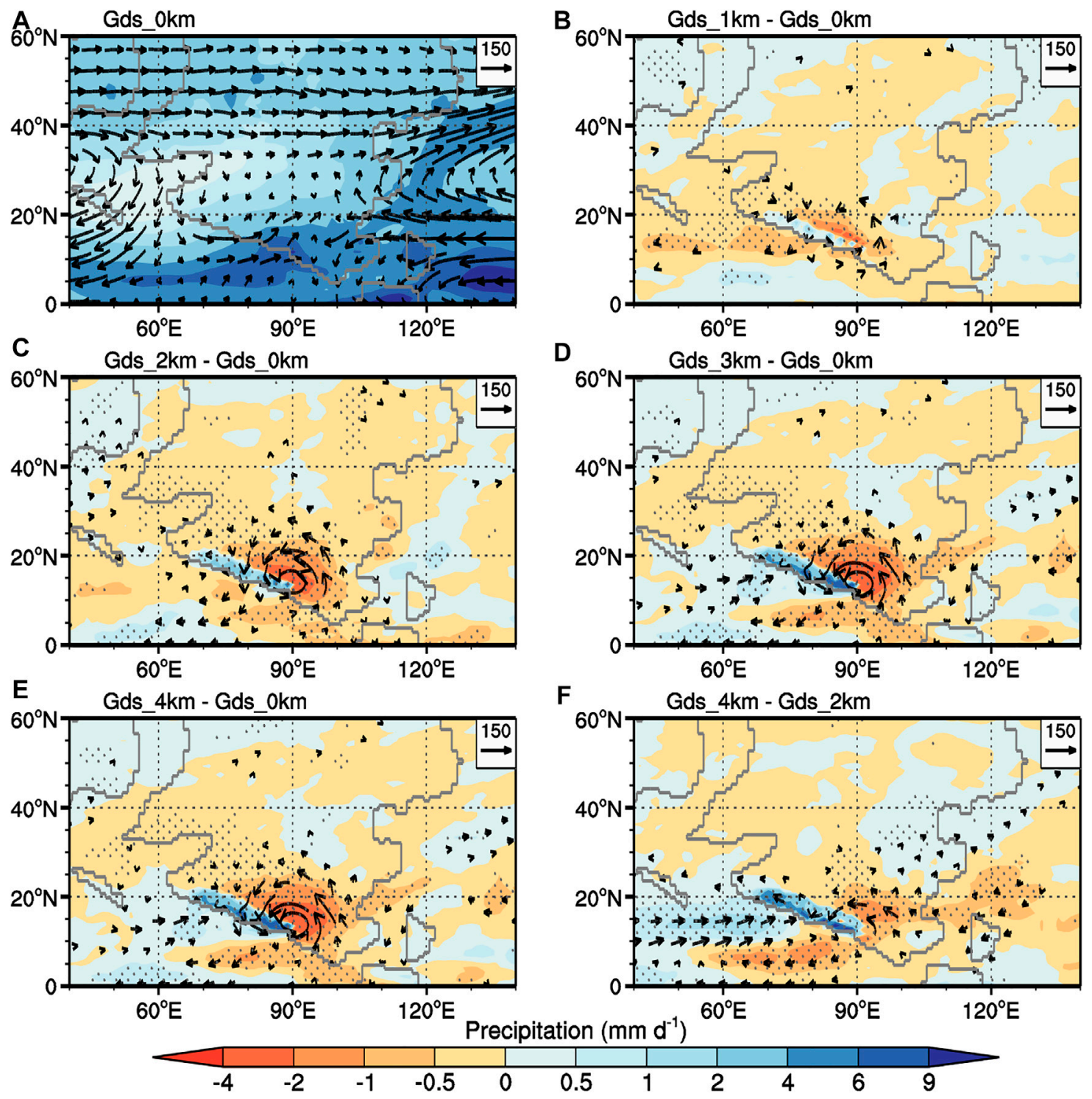

FIGURE 4 | Annual mean precipitation (shaded; units: $\mathrm{mm} \mathrm{d}^{-1}$ ) and vertically integrated water vapor transport (vectors; units: $\mathrm{kg} \mathrm{m}^{-1} \mathrm{~s}^{-1}$ ) of experiment $\mathrm{Gds}$. $0 \mathrm{~km}$ (A) and their differences between experiments Gds_1 km and Gds_0 km (B), Gds_2 km and Gds_0 km (C), Gds_3 km and Gds_0 km (D), Gds_4 km and Gds_0 km (E), and Gds_4 km and Gds_2 km (F). In (B-F), only the areas with confidence levels >95\% (using the Student's t-test) are presented for the water vapor transport and dotted for the precipitation.

million years) of the tectonic evolution or the uplift of the Gangdese Mountains. Consequently, the eccentricity is fixed at 0 and the obliquity is set to $23.3^{\circ}$, which is approximately the average condition over geological timescale. The solar constant is reduced to $1,351.47 \mathrm{~W} \mathrm{~m}^{-2}$, about $0.7 \%$ lower than the presentday solar constant (1361 $\mathrm{W} \mathrm{m}^{-2}$; Gough, 1981).

The fully coupled experiment CoupExp has full ocean bathymetry, and is run for 1,000 model years in order for the surface climate (e.g. temperature, precipitation and sea ice) to reach statistical equilibrium. The monthly SSTs and sea ice fractions averaged over the last 100 years are used as the boundary condition of the atmospheric sensitivity experiments. The high-resolution atmospheric experiments equilibrates quickly and are run for 25 model years, and the last 20 years of data are analyzed and presented herein.

\section{RESULTS}

\section{Drying Effect of the Gangdese Mountains}

The Late Cretaceous climate reconstructed from proxies is much warmer than the present. The annual-mean tropic SSTs could be greater than $30^{\circ} \mathrm{C}$ (Wilson et al., 2002; Forster et al., 2007), and the high-latitude SSTs were above $0^{\circ} \mathrm{C}$ (Huber et al., 2002; Spicer and Herman, 2010). In general, the results of the CoupExp experiment compare well with the SST reconstructions (Tabor 
et al., 2016; Figure 3). This gives us confidence in the model's ability in simulating the Late Cretaceous climate. However, there is large disparity among the tropical proxy data (Figure 3B). The main issue is that some proxy-derived SSTs are much lower than either others or modeled values, which can be explained at least by a few factors (Pearson et al., 2001; Zeebe, 2001; Hay, 2011). Firstly, the early measurements were based on oxygen isotope of planktonic foraminifera, which are diagenetically altered or recrystallized in the sediments (Pearson et al., 2001; Hay, 2011). In addition, some studies did not consider the depth habitat of the planktonic foraminifera used, which may live in subsurface layer, so the reconstructed tropical SSTs look much like the modern water temperature at $100 \mathrm{~m}$ depth (Hay, 2011). Moreover, during Cretaceous greenhouse period with much higher atmospheric $\mathrm{CO}_{2}$ levels, the $\mathrm{pH}$ of the sea water is lower than the present. If this is taken into account, the paleotemperature reconstructed from the oxygen isotopic can be adjusted upward by $2-3.5^{\circ} \mathrm{C}$ (Zeebe, 2001).

The annual precipitation in the interior Asia exhibits a triple mode, with more precipitation in the low (south of $\sim 20^{\circ} \mathrm{N}$ ) and mid (north of $\sim 40^{\circ} \mathrm{N}$ ) latitudes and less precipitation in the midto low-latitudes $\left(\sim 20-40^{\circ} \mathrm{N}\right.$, Figure $\left.4 \mathbf{A}\right)$. In the low latitudes, strong water vapor transport from both the Tethyan and Pacific oceans brings heavy precipitation of $>6 \mathrm{~mm} \mathrm{~d}^{-1}$, while in the mid-latitudes, the water vapor is mainly brought there by the westerlies. All three sources of water vapor, i.e. Tethyan Ocean, Pacific Ocean and westerlies, bring little amount of water vapor to the region in between those two regions. In this middle region (mid-to low-latitudes Asia), precipitation is the least in the west and increases towards the east. The Gangdese Mountains, if present, are located right on the path of water vapor transport from Tethyan Ocean to Asia and expected to deprive large amount of the water vapor. Indeed, the precipitation increases over the mountain range and its upstream, while decreases significantly to the north (Figures $4 \mathbf{B}-\mathbf{F}$ ).

Even with a relatively low altitude of $2 \mathrm{~km}$, the Gangdese Mountains reduce precipitation significantly on the north and east within a belt of $\sim 15^{\circ}$ width adjacent to the mountain range (Figure 4C), compared to the case when the mountain range is absent (experiment Gds_0 km). The effect of the mountain range on precipitation barely reaches $40^{\circ} \mathrm{N}$ and has little effect in the easternmost region of Asia. The most significant reduction of precipitation occurs to the northeast of the east end of the Gangdese Mountains, reaching almost $\sim 3 \mathrm{~mm} \mathrm{~d}^{-1}$. The magnitude and the spatial extent of decrease in precipitation increase with the altitude of the mountains. The pattern of precipitation change is similar to that obtained in Zhang et al. (2018a). They investigated the influence of the Himalaya-TP latitudes on Asian climate and found that precipitation decreased over the East Asia and inland Asia when the Himalaya-TP was located south of $20^{\circ} \mathrm{N}$.

The aridity indices (AI) widely used in the present and past climate change (e.g. Feng and Fu, 2013; Liu et al., 2018; Ma et al., 2021) over Asia are calculated based on the precipitation, surface temperature, relative humidity, wind speed and surface energy fluxes from the climate model output. According to this index, a tongue-shaped arid (A) area extending from the southwest towards the northeast exists over Asia when there is no Gangdese Mountains (Figure 5A). Moving outwards from this arid region, the land surface becomes less dry and gradually changes to semi-arid and dry sub-humid types. Consistent with the change of the precipitation (Figures 4B-E), the dry region expands southwards and eastwards with the altitude of the Gangdese Mountains (Figures 5B-E). By reaching an altitude of $2 \mathrm{~km}$, the arid region deviates from a tongue shape significantly (Figure 5C). Along with the expansion of dry region, the maximum intensity of dryness also exacerbates; hyper-arid (HA) region begins to appear when the Gangdese Mountains are $1 \mathrm{~km}$ high (Figure 5B), and its area increases with the altitude of the Gangdese Mountains (Figures 5B-E).

\section{Paleoelevation of the Gangdese Mountains}

Eolian deposits are widely distributed over the mid-to lowlatitude Asia (Jiang et al., 2004; Jiang et al., 2008; Hasegawa et al., 2012), indicating that the region was arid/semi-arid then (Fang et al., 2016). In fact, the region was often called the Cretaceous desert belt (oriented zonally) in Asia (Hasegawa et al., 2012). The sedimentary records mainly come from eight basins, namely, Gobi (Gb), Ordos (Or), Tarim (Tr), Sichuan (Sc), Simao (Sm), Khorat (Kr), Nima (Nm), and Songliao (Sl) basins in Asia. In the Or basin, eolian dunes were found (Figure 6A; Hasegawa et al., 2012), suggesting the desert was developed there. According to Zhang et al. (2021), most of the arid to hyper-arid land surface in Cretaceous Asia was covered by the desert, so the climate in the Or and $\mathrm{Nm}$ basins corresponds to the arid to hyperarid land types. The other four basins, $\mathrm{Tr}, \mathrm{Sc}, \mathrm{Sm}$ and $\mathrm{Kr}$, containing red-bed (Hasegawa et al., 2012; Figure 6A), which is less dry than that in the Or basin and likely corresponds to the semi-arid (SA) to dry sub-humid (DSH) in late Cretaceous land types. The mudstone and sandstone of the alluvial plains or seasonal lakes in the Gb basin suggest semi-arid or even wetter environments (Jerzykiewicz and Russell, 1991). The records in the Sl basin in the northeast China contain large amount of black mudstone. Based on the climatologically sensitive deposits, oxygen isotope, and paleontology, the Sl basin climate was temperate and humid with relatively abundant rainfall (Wang et al., 2013), which we consider as the modeled semi-humid to humid land types.

The aridity of most of the basins turns out not to be sensitive to the altitude of the Gangdese Mountains (Figure 5), probably because they are too far away from the mountain range. However, the aridity of the Sc, Sm and $\mathrm{Kr}$ basins is highly sensitive to the altitude of the Gangdese Mountains. Among the non-sensitive basins, the simulated wet condition in the Sl basin in all experiments is consistent with the mudstone records (Wang et al., 2013), the simulated mixed condition in the Gb basin is consistent with the mixed types of deposition within that basin (Hasegawa et al., 2009; Jerzykiewicz and Russell, 1991), and the arid land type in the $\mathrm{Nm}$ basin is also in agreement with the evaporitic lacustrine and eolian dune-field deposits (DeCelles et al., 2007). The aridity of the Or basin is underestimated by the model. There is no plausible reason why the Or basin is not dry enough in the simulations but one reason could be that the effect of dust is neglected in our simulations. The semi-direct effect of 

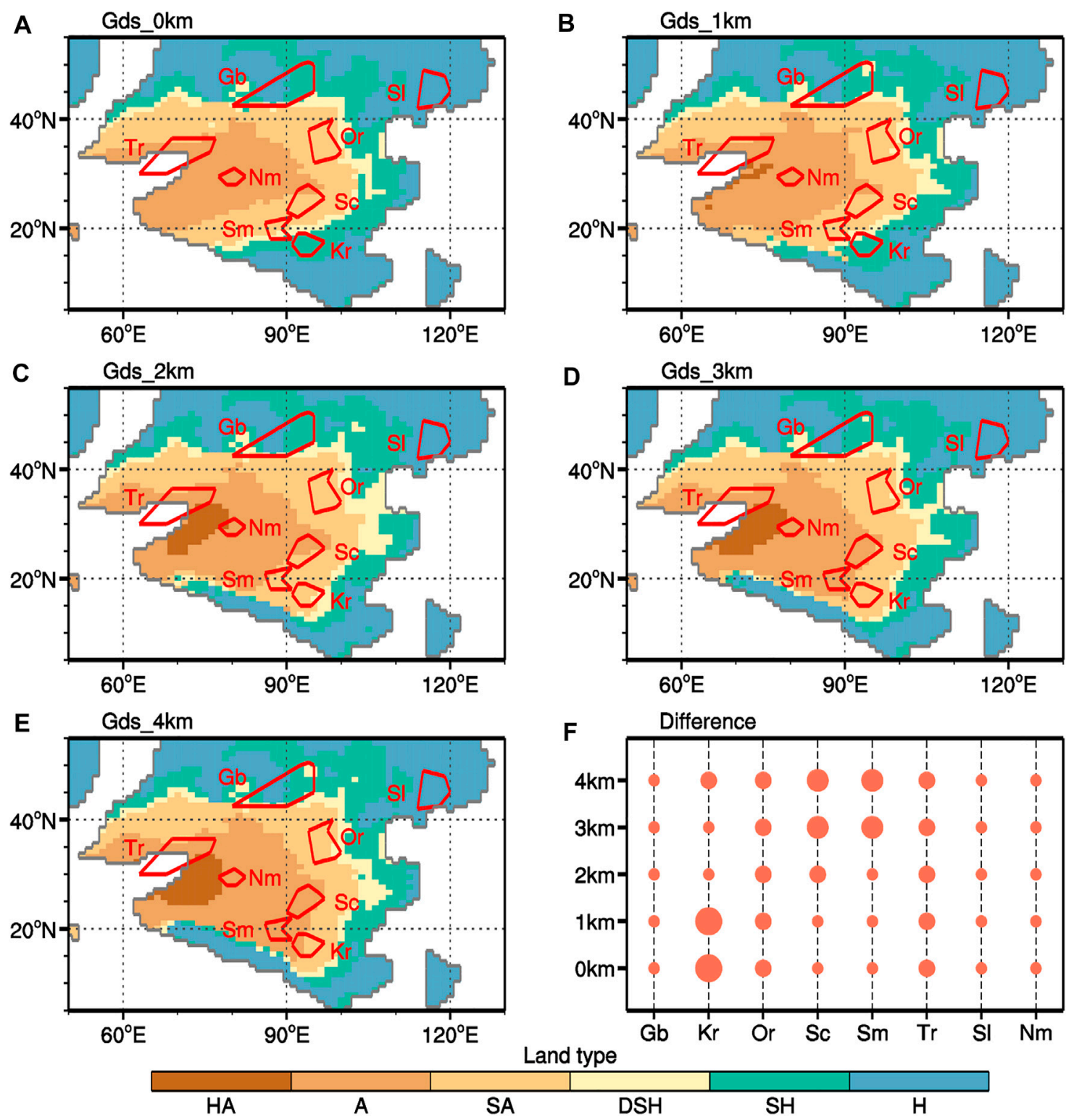

FIGURE 5 | Land types of experiments Gds_0 km (A), Gds_1 km (B), Gds_2 km (C), Gds_3 km (D), Gds_4 km (E), respectively, and difference between modeling results and geological reconstruction in each Basin (F). For the land types in (A-E), H is for the humid type, SH for the semi-humid type, DSH for dry sub-humid type, SA for the semi-arid type, A for the arid type, and HA for the hyper-arid type, respectively; And each irregular polygon in A-E represents a basin (DeCelles et al., 2007; Hasegawa et al., 2012; Wang et al., 2013), and abbreviated basin names are as follows: Gb = Gobi, Tr= Tarim, Or= Ordos, Sc = Sichuan, Sm = Simao, Kr= Khorat, $\mathrm{SI}=$ Songliao, $\mathrm{Nm}=$ Nima .

atmospheric dust is that it can absorb sunlight and evaporates the surrounding clouds, especially those above the dust; the dust can also increase the number of cloud condensation nuclei, reducing the size of cloud droplets and increasing the lifetime of cloud droplets. Both of these effects can reduce the amount of rain. Another significant deviation between the modeled and proxyinferred aridity appears for the Tr basin. This basin is arid in all simulations (Figure 5), which is a little drier than that indicated by the prevalent red beds in that region (Figure 6A). However, the red bed in the Tr basin might not be treated as robust evidence of semi-arid to dry sub-humid condition because the region was likely influenced by a few transgression-regression cycles (Jolivet et al., 2018; Zhang et al., 2018b).

The qualitative nature of both the modeled and reconstructed aridity does not warrant a quantitative comparison. Therefore, we compare them qualitatively in Figure 5F, in which the size of the filled circles is proportionate to the difference between modeled $\mathrm{AI}$ and reconstructed aridity. The $\mathrm{Kr}$ basin requires the Gangdese Mountains to be higher than $1 \mathrm{~km}$ (Figures 5C-E); the modeled $\mathrm{Sm}$ and $\mathrm{Sc}$ basins become arid when the Gangdese Mountains reach $3 \mathrm{~km}$ or $4 \mathrm{~km}$ (Figures 5D,E), so they require a height of lower that $3 \mathrm{~km}$. Synthesizing the comparisons gives an optimum 

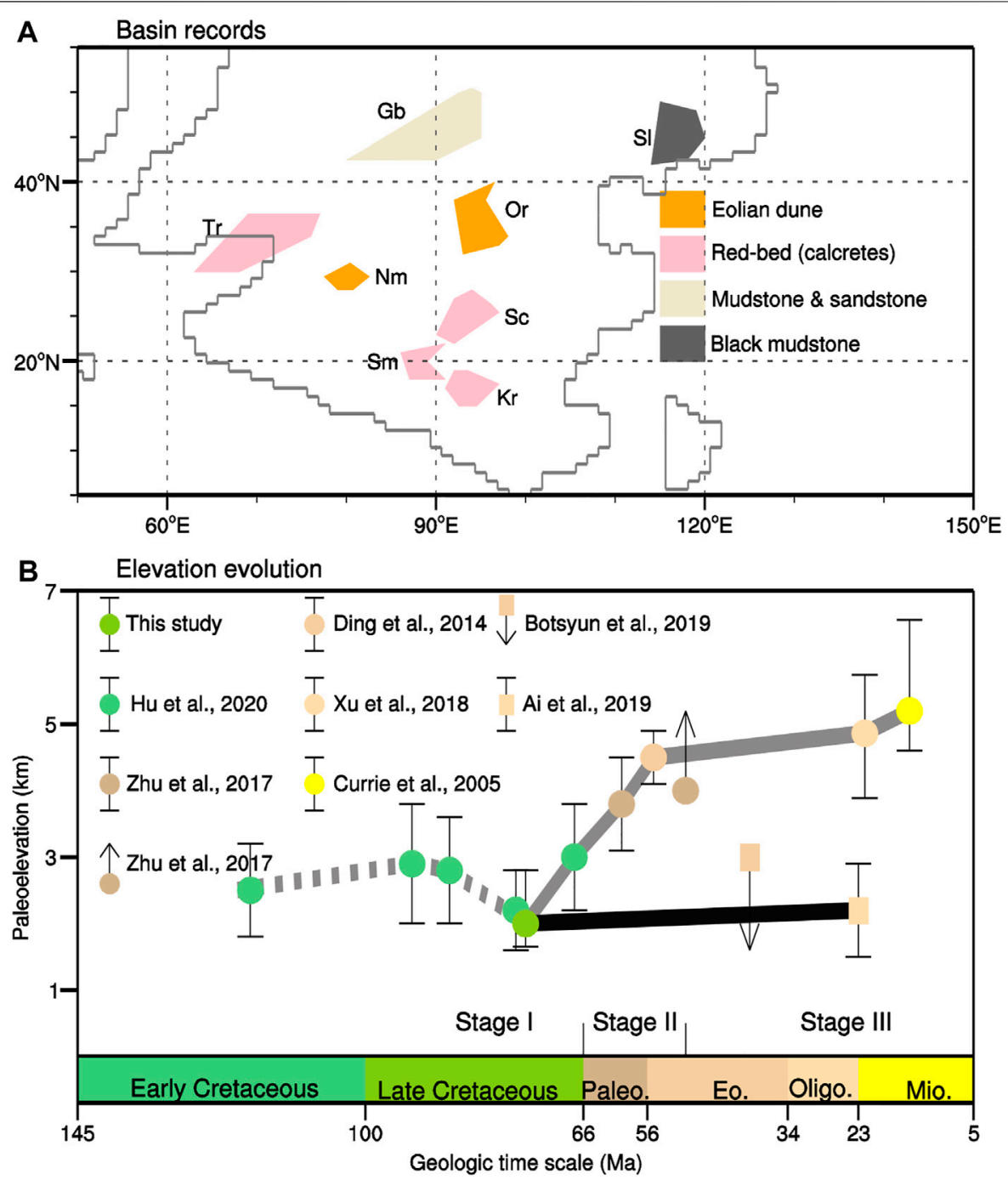

FIGURE 6 | The sedimentary records in mid-to low-latitude Asian basins (A), and evolution of the Gangdese Mountains from Cretaceous to Miocene (B). In B, The dashed line represents the relatively stable stage of the Gangdese Mountains with a medium height from the Early Cretaceous to Late Cretaceous based on our result and Hu et al. (2020), the dots with error bars from Paleocene to Miocene are from Ai et al. (2019), Currie et al. (2005), Ding et al. (2014), Khan et al. (2014), and Xu et al. (2018), and the dotted data with arrow represents the least elevation (Zhu et al., 2017) or the highest elevation (Botsyun et al., 2019).

height of the Gangdese Mountains at $\sim 2 \mathrm{~km}$, with a maximum possible range of $1-3 \mathrm{~km}$ (Figure 5F). Hu et al. (2020) concluded that the Southern Lhasa terrain had attained $2.2 \pm 0.6 \mathrm{~km}$ at $76.53 \pm 2.00 \mathrm{Ma}$ based on the whole-rock $\mathrm{Sr} / \mathrm{Y}$ and $\mathrm{La} / \mathrm{Yb}$ ratios, where the age is within the late Cretaceous considered in this study. They inferred the range of the paleoelevation of the Gangdese Mountains might be $1.6-2.8 \mathrm{~km}$, consistent with our estimate.

In this study, only the Gangdese Mountains from the Southern Lhasa terrane is considered. A proto-Tibetan Plateau including Lhasa and Qiangtang terranes might have uplifted during the Cretaceous but its central and northern parts was lower than that of the Gangdese Mountains (Hu et al., 2020). Previous modeling studies have shown that the influence of modern Tibet Plateau on the East Asian monsoon is primarily due to the effect of Himalayas on its southern edge (Boos and Kuang, 2010;
Acosta and Huber, 2020), which may be analogous to influence of the proto-Tibetan Plateau and the Gangdese Mountains. Therefore, ignoring the Lhasa terrane is not expected to have significant influence the main results of this study.

\section{DISCUSSION}

There have been multiple attempts to reconstruct the paleoaltitude of the Gangdese Mountains for the post IndiaAsia collision period (e.g. Spicer et al., 2003; Ding et al., 2014; Ai et al., 2019), but to the best of our knowledge, few have been made for the period before their collision, such as the Late Cretaceous. Since the uplift of Lhasa terrane has been widely reported before the India-Asia Collisions (Kapp et al., 2005; DeCelles et al., 2007; 
Kapp et al., 2007; Sun et al., 2015), there is no reason to believe that the Gangdese Mountains did not rise during that time. Our results may provide an estimate for the early evolution of the Gangdese Mountains (Figure 6B).

The $\sim 2 \mathrm{~km}$ altitude of the Gangdese Mountains during the Late Cretaceous as constrained herein can reconcile some evidence for their evolution both before and after this period. During the Early Cretaceous (144-100 Ma), most of the Lhasa block was low (Murphy et al., 1997), implying a not high Gangdese mountain range as well. The Lhasa block was uplifted due to its collision with the Qiangtang block (Murphy et al., 1997) and/or the subduction of the Neotethyan oceanic lithosphere (Kapp et al., 2005, 2007). Recent paleoelevation reconstruction suggested that the paleoelevation of the Gangdese Mountains was relatively stable at $\sim 2.5 \mathrm{~km}$ during the Cretaceous, though it decreased to $\sim 2 \mathrm{~km}$ for the extensional environment ( $\mathrm{Hu}$ et al., 2020). After that, there are two different pathways that have been envisioned for its evolution. In the first pathway, the Gangdese Mountains are thought to have reached a high elevation of $4-5 \mathrm{~km}$ during Eocene-Miocene (grey line in Figure 6B), while in the other, they only reached an elevation of $<3 \mathrm{~km}$ by the latest Oligocene (black line in Figure 6B).

The whole uplifting history of the Gangdese Mountains, consistent with the first pathway, may be roughly divided into three stages (Figure 6B). Stage I is characterized by a relatively stable paleoelevation between $\sim 2-3 \mathrm{~km}$ before the India-Asia collision. This relatively stable stage is supported by the whole-rock Sr/Y and $\mathrm{La} / \mathrm{Yb}$ ratios ( $\mathrm{Hu}$ et al., 2020) and a constant convergence rate between the Indian subcontinent and the paleo-Asian continent (Wang et al., 2020), suggesting significant crustal shortening prior to $69 \mathrm{Ma}$ (England and Searle, 1986; Kapp et al., 2007; Leier et al., 2007), probably resulted from the subduction of the Neotethyan oceanic lithosphere (Murphy et al., 1997; Kapp et al., 2003, 2005). When the Indian subcontinent collided with the Asian continent, the Gangdese Mountains was uplifted to $4.5 \pm 0.4 \mathrm{~km}$ based on the variation of $\delta^{18} \mathrm{O}$ (Ding et al., 2014) and spatial and temporal variations of crust thickness (Zhu et al., 2017). Thus this uplift was accomplished in a relatively short time period, and may be distinguished as a new stage, i.e. Stage II (Figure 6B). After Stage II, the elevation of the Gangdese Mountains rose further but at a very slow rate from Eocene to middle Miocene, induced by the continued convergence of the Indian and Asian plates (Spicer et al., 2003). This relative quiescent state is referred to as Stage III, and the Gangdese Mountains reached $\sim 5 \mathrm{~km}$ around earlymiddle Miocene (Spicer et al., 2003; Currie et al., 2005; Khan et al., 2014; Currie et al., 2016; Xu et al., 2018).

In the second pathway, the elevation of the Gangdese Mountains remained low till the latest Oligocene. By comparing the modeled and reconstructed $\delta^{18} \mathrm{O}$, Botsyun et al. (2019) suggested that the TP only reached low to moderate $(<3 \mathrm{~km})$ elevations during the Eocene $(\sim 40 \mathrm{Ma})$. This greatly reduced the likelihood of the Gangdese Mountains reaching higher elevation at an earlier time period. Discovery of the fossil flora, representing deciduous, broad-leaf vegetation, suggests a temperate, humid environment with paleoelevation of only $1.5-2.9 \mathrm{~km}$ at $23.3 \mathrm{Ma}$ (Ai et al., 2019). This pathway is represented by a thick black line in Figure 6B. Because the IndiaAsia collision occurred in early Paleogene (Hu et al., 2015, Hu et al., 2016) and continued afterwards, the uplift of the Gangdese Mountains coming to a halt during this time needs an explanation if this was indeed true what happened.

\section{CONCLUSION}

The climate effect of the Gangdese Mountains is simulated in this study using the general circulation model CESM1.2.2. The rise of the Gangdese Mountains causes drying on its immediate northeast in the downwind direction, and the drying exacerbates with the altitude of the mountain range. Therefore, the aridity in the $\mathrm{Kr}, \mathrm{Sc}$ and $\mathrm{Sm}$ basins is sensitive to the altitude of the Gangdese Mountains and able to provide a semi-quantitative constraint on the altitude of the Gangdese Mountains. The aridity index is further calculated for this region, and its comparison with the sedimentary records suggests that Gangdese Mountains should be higher than $1 \mathrm{~km}$ but lower than $3 \mathrm{~km}$ during the Late Cretaceous, most likely $\sim 2 \mathrm{~km}$.

\section{DATA AVAILABILITY STATEMENT}

The datasets presented in this study can be found in online repositories. The names of the repository/repositories and accession number(s) can be found below: https://zenodo.org/ record/4300467\#.YYi0bYgzZPa.

\section{AUTHOR CONTRIBUTIONS}

The idea was provided by the JZ and XF. JZ conducted the modeling experiments and collected the geological records. JZ and YL wrote the manuscript. TZ, CZ, and $\mathrm{CW}$ gave much advance for this manuscript.

\section{FUNDING}

This study was co-supported by the National Natural Science Foundation of China (Grants 42002129, 41790450, 41888101, and 41620104002), the Second Tibetan Plateau Scientific Expedition and Research (STEP) program (Grant 2019QZKK0707), the Strategic Priority Research Program of Chinese Academy of Sciences (Grant XDA20070201), the China Postdoctoral Science Foundation (Grant 2017M611015), and China Scholarship Council (CSC).

\section{ACKNOWLEDGMENTS}

We sincerely thank Dr. Jacob Ogilvie Sewall (Kutztown University of Pennsylvania) for providing the 
paleogeography and paleovegetation data and Dr. Yibo Yang (Institute of Tibetan Plateau Research, Chinese Academy of Sciences) for reviewing our manuscript and providing some

\section{REFERENCES}

Acosta, R. P., and Huber, M. (2020). Competing Topographic Mechanisms for the Summer Indo-Asian Monsoon. Geophys. Res. Lett. 47, e2019GL085112. doi:10.1029/2019gl085112

Ai, K., Shi, G., Zhang, K., Ji, J., Song, B., Shen, T., et al. (2019). The Uppermost Oligocene Kailas Flora from Southern Tibetan Plateau and its Implications for the Uplift History of the Southern Lhasa Terrane. Palaeogeogr. Palaeoclimatol. Palaeoecol. 515, 143-151. doi:10.1016/j.palaeo.2018.04.017

An, Z., Kutzbach, J. E., Prell, W. L., and Porter, S. C. (2001). Evolution of Asian Monsoons and Phased Uplift of the Himalaya-Tibetan Plateau since Late Miocene Times. Nature 411 (6833), 62-66. doi:10.1038/35075035

Boos, W. R., and Kuang, Z. (2010). Dominant Control of the South Asian Monsoon by Orographic Insulation Versus Plateau Heating. Nature 463 (7278), 218-222. doi:10.1038/nature08707

Botsyun, S., Sepulchre, P., Donnadieu, Y., Risi, C., Licht, A., and Caves Rugenstein, J. K. (2019). Revised Paleoaltimetry Data Show Low Tibetan Plateau Elevation during the Eocene. Science 363 (6430), 1436. doi: $10.1126 /$ science.aaq 1436

Currie, B. S., Rowley, D. B., and Tabor, N. J. (2005). Middle Miocene Paleoaltimetry of Southern Tibet: Implications for the Role of Mantle Thickening and Delamination in the Himalayan Orogen. Geology 33 (3), 181-184. doi:10.1130/g21170.1

Currie, B. S., Polissar, P. J., Rowley, D. B., Ingalls, M., Li, S., Olack, G., et al. (2016). Multiproxy Paleoaltimetry of the Late Oligocene-Pliocene Oiyug Basin, Southern Tibet. Am. J. Sci. 316, 401-436. doi:10.2475/05.2016.01

DeCelles, P. G., Kapp, P., Ding, L., and Gehrels, G. E. (2007). Late Cretaceous to Middle Tertiary basin Evolution in the central Tibetan Plateau: Changing Environments in Response to Tectonic Partitioning, Aridification, and Regional Elevation Gain. Geol. Soc. America Bull. 119 (5-6), 654-680. doi:10.1130/ b26074.1

Dewey, J. F., Shackleton, R. M., Chengfa, C., and Yiyin, S. (1988). The Tectonic Evolution of the Tibetan Plateau. Phil. Trans. R. Soc. Lond. A. 327 (1594), 379-413. doi:10.1098/rsta.1988.0135

Ding, L., and Lai, Q. (2003). New Geological Evidence of Crustal Thickening in the Gangdese Block Prior to the Indo-Asian Collision. Chin. Sci. Bull. 48 (15), 1604-1610. doi:10.1007/bf03183969

Ding, L., Xu, Q., Yue, Y., Wang, H., Cai, F., and Li, S. (2014). The Andean-Type Gangdese Mountains: Paleoelevation Record from the Paleocene-Eocene Linzhou Basin. Earth Planet. Sci. Lett. 392, 250-264. doi:10.1016/ j.epsl.2014.01.045

England, P., and Searle, M. (1986). The Cretaceous-Tertiary Deformation of the Lhasa Block and its Implications for Crustal Thickening in Tibet. Tectonics 5 (1), 1-14. doi:10.1029/TC005i001p00001

Fang, X., Song, C., Yan, M., Zan, J., Liu, C., Sha, J., et al. (2016). Mesozoic Litho- and Magneto-Stratigraphic Evidence from the Central Tibetan Plateau for Megamonsoon Evolution and Potential Evaporites. Gondwana Res. 37, 110-129. doi:10.1016/j.gr.2016.05.012

Farnsworth, A., Lunt, D. J., Robinson, S. A., Valdes, P. J., Roberts, W. H. G., Clift, P. D., et al. (2019). Past East Asian Monsoon Evolution Controlled by Paleogeography, Not CO 2. Sci. Adv. 5 (10), 1697. doi:10.1126/sciadv.aax1697

Feng, S., and Fu, Q. (2013). Expansion of Global Drylands under a Warming Climate. Atmos. Chem. Phys. 13 (19), 10081-10094. doi:10.5194/acp-13-100812013

Fluteau, F., Besse, J., Broutin, J., and Ramstein, G. (2001). The Late Permian Climate. What Can Be Inferred from Climate Modelling Concerning Pangea Scenarios and Hercynian Range Altitude? Palaeogeogr. Palaeoclimatol. Palaeoecol. 167 (1), 39-71. doi:10.1016/S0031-0182(00)00230-3

Forster, A., Schouten, S., Moriya, K., Wilson, P. A., and Sinninghe Damsté, J. S. (2007). Tropical Warming and Intermittent Cooling during the Cenomanian/ Turonian Oceanic Anoxic Event 2: Sea Surface Temperature Records from the reconstructive suggestions. The model simulations were performed on TianHe-2, thanks for the support of National Supercomputer Center in Guangzhou (NSCCGZ).

Equatorial Atlantic. Paleoceanography 22 (1), PA1219. doi:10.1029/ 2006PA001349

Gough, D. O. (1981). Solar interior Structure and Luminosity Variations. Solar Phys. 74 (1), 21-34. doi:10.1007/bf00151270

Hahn, D. G., and Manabe, S. (1975). The Role of Mountains in the South Asian Monsoon Circulation. J. Atmos. Sci. 32 (8), 1515-1541. doi:10.1175/15200469(1975)032<1515:tromit>2.0.co;2

Hasegawa, H., Tada, R., Ichinnorov, N., and Minjin, C. (2009). Lithostratigraphy and Depositional Environments of the Upper Cretaceous Djadokhta Formation, Ulan Nuur Basin, Southern Mongolia, and its Paleoclimatic Implication. J. Asian Earth Sci. 35 (1), 13-26. doi:10.1016/j.jseaes.2008.11.010

Hasegawa, H., Tada, R., Jiang, X., Suganuma, Y., Imsamut, S., Charusiri, P., et al. (2012). Drastic Shrinking of the Hadley Circulation during the MidCretaceous Supergreenhouse. Clim. Past 8 (4), 1323-1337. doi:10.5194/ cp-8-1323-2012

Hay, W. W. (2011). Can Humans Force a Return to a 'Cretaceous' Climate? Sediment. Geology. 235 (1-2), 5-26. doi:10.1016/j.sedgeo.2010.04.015

Hu, X., Garzanti, E., Moore, T., and Raffi, I. (2015). Direct Stratigraphic Dating of India-Asia Collision Onset at the Selandian (Middle Paleocene, $59 \pm 1 \mathrm{Ma}$ ). Geology 43 (10), 859-862. doi:10.1130/g36872.1

Hu, X., Garzanti, E., Wang, J., Huang, W., An, W., and Webb, A. (2016). The Timing of India-Asia Collision Onset - Facts, Theories, Controversies. EarthScience Rev. 160, 264-299. doi:10.1016/j.earscirev.2016.07.014

Hu, F., Wu, F., Chapman, J. B., Ducea, M. N., Ji, W., and Liu, S. (2020). Quantitatively Tracking the Elevation of the Tibetan Plateau since the Cretaceous: Insights from Whole-Rock $\mathrm{Sr} / \mathrm{Y}$ and $\mathrm{La} / \mathrm{Yb}$ Ratios. Geophys. Res. Lett. 47, e2020GL089202. doi:10.1029/2020gl089202

Huber, B. T., Norris, R. D., and MacLeod, K. G. (2002). Deep-Sea Paleotemperature Record of Extreme Warmth during the Cretaceous. Geology 30 (2), 123-126. doi:10.1130/0091-7613(2002)030<0123:dsproe >2.0.co;2

Jerzykiewicz, T., and Russell, D. A. (1991). Late Mesozoic Stratigraphy and Vertebrates of the Gobi Basin. Cretaceous Res. 12 (4), 345-377. doi:10.1016/ 0195-6671(91)90015-5

Jiang, X., Pan, Z., Xie, Y., and Li, M. (2004). Cretaceous Desert Cycles, Wind Direction and Hydrologic Cycle Variations in Ordos Basin: Evidence for Cretaceous Climatic Unequability. Sci. China Ser. D-Earth Sci. 47 (8), 727. doi:10.1360/02yd0031

Jiang, X., Pan, Z., Xu, J., Li, X., Xie, G., and Xiao, Z. (2008). Late Cretaceous Aeolian Dunes and Reconstruction of Palaeo-Wind Belts of the Xinjiang Basin, Jiangxi Province, China. Palaeogeogr. Palaeoclimatol. Palaeoecol. 257 (1-2), 58-66. doi:10.1016/j.palaeo.2007.09.012

Jolivet, M., Boulvais, P., Barrier, L., Robin, C., Heilbronn, G., Ledoyen, J., et al. (2018). Oxygen and Carbon Stable Isotope Composition of Cretaceous to Pliocene Calcareous Paleosols in the Tian Shan Region (Central Asia): Controlling Factors and Paleogeographic Implications. Geosciences 8 (9), 330. doi:10.3390/geosciences 8090330

Kapp, P., Murphy, M. A., Yin, A., Harrison, T. M., Ding, L., and Guo, J. (2003). Mesozoic and Cenozoic Tectonic Evolution of the Shiquanhe Area of Western Tibet. Tectonics 22 (4), a-n. doi:10.1029/2001TC001332

Kapp, P., Yin, A., Harrison, T. M., and Ding, L. (2005). Cretaceous-Tertiary Shortening, Basin Development, and Volcanism in central Tibet. Geol. Soc. America Bull. 117 (7-8), 865-878. doi:10.1130/b25595.1

Kapp, P., DeCelles, P. G., Gehrels, G. E., Heizler, M., and Ding, L. (2007). Geological Records of the Lhasa-Qiangtang and Indo-Asian Collisions in the Nima Area of Central Tibet. Geol. Soc. America Bull. 119 (7-8), 917-933. doi:10.1130/b26033.1

Khan, M. A., Spicer, R. A., Bera, S., Ghosh, R., Yang, J., Spicer, T. E. V., et al. (2014). Miocene to Pleistocene Floras and Climate of the Eastern Himalayan Siwaliks, and New Palaeoelevation Estimates for the Namling-Oiyug Basin, Tibet. Glob. Planet. Change 113, 1-10. doi:10.1016/j.gloplacha.2013.12.003 
Kitoh, A. (2004). Effects of Mountain Uplift on East Asian Summer Climate Investigated by a Coupled Atmosphere-Ocean GCM. J. Clim. 17 (4), 783-802. doi:10.1175/1520-0442(2004)017<0783:eomuoe >2.0.co;2

Kutzbach, J. E., Prell, W. L., and Ruddiman, W. F. (1993). Sensitivity of Eurasian Climate to Surface Uplift of the Tibetan Plateau. J. Geology. 101 (2), 177-190. doi:10.1086/648215

Leier, A. L., DeCelles, P. G., Kapp, P., and Gehrels, G. E. (2007). Lower Cretaceous Strata in the Lhasa Terrane, Tibet, with Implications for Understanding the Early Tectonic History of the Tibetan Plateau. J. Sediment. Res. 77 (10), 809-825. doi:10.2110/jsr.2007.078

Liebke, U., Appel, E., Ding, L., Neumann, U., Antolin, B., and Xu, Q. (2010). Position of the Lhasa Terrane Prior to India-Asia Collision Derived from Palaeomagnetic Inclinations of $53 \mathrm{Ma}$ Old Dykes of the Linzhou Basin: Constraints on the Age of Collision and post-collisional Shortening within the Tibetan Plateau. Geophys. J. Int. 182 (3), 1199-1215. doi:10.1111/j.1365246X.2010.04698.x

Liu, X., and Yin, Z.-Y. (2002). Sensitivity of East Asian Monsoon Climate to the Uplift of the Tibetan Plateau. Palaeogeogr. Palaeoclimatol. Palaeoecol. 183, 223-245. doi:10.1016/S0031-0182(01)00488-6

Liu, S., Jiang, D., and Lang, X. (2018). A Multi-Model Analysis of Moisture Changes during the Last Glacial Maximum. Quat. Sci. Rev. 191, 363-377. doi:10.1016/j.quascirev.2018.05.029

Ma, D., Boos, W., and Kuang, Z. (2014). Effects of Orography and Surface Heat Fluxes on the South Asian Summer Monsoon. J. Clim. 27 (17), 6647-6659. doi:10.1175/jcli-d-14-00138.1

Ma, N., Szilagyi, J., and Zhang, Y. (2021). Calibration-Free Complementary Relationship Estimates Terrestrial Evapotranspiration Globally. Water Resour. Res. 57, e2021WR029691. doi:10.1029/2021wr029691

Murphy, M. A., Yin, A., Harrison, T. M., Dür, S. B., Chen, Z., Ryerson, F. J., et al. (1997). Did the Indo-Asian Collision Alone Create the Tibetan Plateau? J. Geophys. Res. 25 (8), 719-722. doi:10.1130/0091-7613(1997)025<0719: DTIACA $>2.3$. CO;2

Najman, Y., Appel, E., Boudagher-Fadel, M., Bown, P., Carter, A., Garzanti, E., et al. (2010). Timing of India-Asia Collision: Geological, Biostratigraphic, and Palaeomagnetic Constraints. J. Geophys. Res. Solid Earth 115, 7673. doi:10.1029/2010jb007673

Pearson, P. N., Ditchfield, P. W., Singano, J., Harcourt-Brown, K. G., Nicholas, C. J., Olsson, R. K., et al. (2001). Warm Tropical Sea Surface Temperatures in the Late Cretaceous and Eocene Epochs. Nature 413 (6855), 481-487. doi:10.1038/ 35097000

Qiu, J. (2014). Tibet Mountainous Long before Himalayas. Nature. doi:10.1038/ nature.2014.15191

Scotese, C. R., and Wright, N. (2018). PALEOMAP Paleodigital Elevation Models (PaleoDEMS) for the Phanerozoic PALEOMAP Project. Available at: https://www.earthbyte.org/paleodem-resource-scotese-and-wright$2018 /$.

Sewall, J. O., van de Wal, R. S. W., van der Zwan, K., van Oosterhout, C., Dijkstra, H. A., and Scotese, C. R. (2007). Climate Model Boundary Conditions for Four Cretaceous Time Slices. Clim. Past 3 (4), 647-657. doi:10.5194/cp-3-647-2007

Spicer, R. A., and Herman, A. B. (2010). The Late Cretaceous Environment of the Arctic: A Quantitative Reassessment Based on Plant Fossils. Palaeogeogr. Palaeoclimatol. Palaeoecol. 295 (3-4), 423-442. doi:10.1016/ j.palaeo.2010.02.025

Spicer, R. A., Harris, N. B. W., Widdowson, M., Herman, A. B., Guo, S., Valdes, P. J., et al. (2003). Constant Elevation of Southern Tibet over the Past 15 Million Years. Nature 421 (6923), 622-624. doi:10.1038/ nature 01356

Sun, G., Hu, X., Sinclair, H. D., BouDagher-Fadel, M. K., and Wang, J. (2015). Late Cretaceous Evolution of the Coqen Basin (Lhasa Terrane) and Implications for Early Topographic Growth on the Tibetan Plateau. Geol. Soc. America Bull. 127 (7-8), 1001-1020. doi:10.1130/b31137.1

Tabor, C. R., Poulsen, C. J., Lunt, D. J., Rosenbloom, N. A., Otto-Bliesner, B. L., Markwick, P. J., et al. (2016). The Cause of Late Cretaceous Cooling: A Multimodel-Proxy Comparison. Geology 44 (11), 963-966. doi:10.1130/ g38363.1

Tan, X., Gilder, S., Kodama, K. P., Jiang, W., Han, Y., Zhang, H., et al. (2010). New Paleomagnetic Results from the Lhasa Block: Revised Estimation of Latitudinal
Shortening Across Tibet and Implications for Dating the India-Asia Collision. Earth Planet. Sci. Lett. 293 (3-4), 396-404. doi:10.1016/j.epsl.2010.03.013

Tapponnier, P., Zhiqin, X., Roger, F., Meyer, B., Arnaud, N., Wittlinger, G., et al. (2001). Oblique Stepwise Rise and Growth of the Tibet Plateau. Science 294 (5547), 1671-1677. doi:10.1126/science.105978

Valdes, P. J., Lin, D., Farnsworth, A., Spicer, R. A., Li, S.-H., and Tao, S. (2019). Comment on "Revised Paleoaltimetry Data Show Low Tibetan Plateau Elevation during the Eocene". Science 365, eaax8474. doi:10.1126/ science.aax 8474

Vertenstein, M., Bertini, A., Craig, T., Edwards, J., Levy, M., Mai, A., et al. (2013). Cesm User's Guide (cesm1.2 Release Series User's Guide). NCAR technical note.

Wang, C., Zhao, X., Liu, Z., Lippert, P. C., Graham, S. A., Coe, R. S., et al. (2008). Constraints on the Early Uplift History of the Tibetan Plateau. Natl. Acad. Sci. United States America 105 (13), 4987-4992. doi:10.1073/ pnas. 0703595105

Wang, C., Scott, R. W., Wan, X., Graham, S. A., Huang, Y., Wang, P., et al. (2013). Late Cretaceous Climate Changes Recorded in Eastern Asian Lacustrine Deposits and North American Epieric Sea Strata. Earth-Science Rev. 126, 275-299. doi:10.1016/j.earscirev.2013.08.016

Wang, C., Dai, J., Zhao, X., Li, Y., Graham, S. A., He, D., et al. (2014a). OutwardGrowth of the Tibetan Plateau during the Cenozoic: A Review. Tectonophysics 621, 1-43. doi:10.1016/j.tecto.2014.01.036

Wang, Y., Huang, C., Sun, B., Quan, C., Wu, J., and Lin, Z. (2014b). Paleo-CO2 Variation Trends and the Cretaceous Greenhouse Climate. Earth-Science Rev. 129, 136-147. doi:10.1016/j.earscirev.2013.11.001

Wang, J.-G., Hu, X., Garzanti, E., BouDagher-Fadel, M. K., Liu, Z.-C., Li, J., et al. (2020). From Extension to Tectonic Inversion: Mid-cretaceous Onset of Andean-type Orogeny in the Lhasa Block and Early Topographic Growth of Tibet. GSA Bull. 132, 2432-2454. doi:10.1130/b35314.1

Wilson, P. A., Norris, R. D., and Cooper, M. J. (2002). Testing the Cretaceous Greenhouse Hypothesis Using Glassy Foraminiferal Calcite from the Core of the Turonian Tropics on Demerara Rise. Geology 30 (7), 607-610. doi:10.1130/ 0091-7613(2002)030<0607:ttcghu >2.0.co;2

Wu, G., Liu, Y., Dong, B., Liang, X., Duan, A., Bao, Q., et al. (2012a). Revisiting Asian Monsoon Formation and Change Associated with Tibetan Plateau Forcing: I. Formation. Clim. Dyn. 39 (5), 1169-1181. doi:10.1007/s00382012-1334-z

Wu, G., Liu, Y., He, B., Bao, Q., Duan, A., and Jin, F.-F. (2012b). Thermal Controls on the Asian Summer Monsoon. Sci. Rep. 2, 404. doi:10.1038/ srep00404

Wu, F.-Y., Ji, W.-Q., Wang, J.-G., Liu, C.-Z., Chung, S.-L., and Clift, P. D. (2014). Zircon U-Pb and Hf Isotopic Constraints on the Onset Time of India-Asia Collision. Am. J. Sci. 314, 548-579. doi:10.2475/02.2014.04

Xu, Q., Ding, L., Spicer, R. A., Liu, X., Li, S., and Wang, H. (2018). Stable Isotopes Reveal Southward Growth of the Himalayan-Tibetan Plateau since the Paleocene. Gondwana Res. 54, 50-61. doi:10.1016/j.gr.2017.10.005

Yeh, Y.-C., and Chang, C.-C. (1974). A Preliminary Experimental Simulation on the Heating Effect of the Tibetan Plateau on the General Circulation over Eastern Asia in Summer. Scientia Sinica 17 (3), 397-420. doi:10.1360/ya197417-3-397

Zeebe, R. E. (2001). Seawater pH and Isotopic Paleotemperatures of Cretaceous Oceans. Palaeogeogr. Palaeoclimatol. Palaeoecol. 170, 49-57. doi:10.1016/ S0031-0182(01)00226-7

Zhang, Z., Wang, H., Guo, Z., and Jiang, D. (2007). Impacts of Tectonic Changes on the Reorganization of the Cenozoic Paleoclimatic Patterns in China. Earth Planet. Sci. Lett. 257 (3-4), 622-634. doi:10.1016/j.epsl.2007.03.024

Zhang, R., Jiang, D., Zhang, Z., and Yu, E. (2015). The Impact of Regional Uplift of the Tibetan Plateau on the Asian Monsoon Climate. Palaeogeogr. Palaeoclimatol. Palaeoecol. 417, 137-150. doi:10.1016/ j.palaeo.2014.10.030

Zhang, R., Jiang, D., Ramstein, G., Zhang, Z., Lippert, P. C., and Yu, E. (2018a). Changes in Tibetan Plateau Latitude as an Important Factor for Understanding East Asian Climate since the Eocene: A Modeling Study. Earth Planet. Sci. Lett. 484, 295-308. doi:10.1016/j.epsl.2017.12.034

Zhang, S., Hu, X., Han, Z., Li, J., and Garzanti, E. (2018b). Climatic and Tectonic Controls on Cretaceous-Palaeogene Sea-Level Changes Recorded in the Tarim 
Epicontinental Sea. Palaeogeogr. Palaeoclimatol. Palaeoecol. 501, 92-110. doi:10.1016/j.palaeo.2018.04.008

Zhang, J., Liu, Y., Fang, X., Wang, C., and Yang, Y. (2019). Large Dry-Humid Fluctuations in Asia during the Late Cretaceous Due to Orbital Forcing: A Modeling Study. Palaeogeogr. Palaeoclimatol. Palaeoecol. 533, 109230. doi:10.1016/j.palaeo.2019.06.003

Zhang, J., Liu, Y., Flögel, S., Zhang, T., Wang, C., and Fang, X. (2021). Altitude of the East Asian Coastal Mountains and Their Influence on Asian Climate during Early Late Cretaceous. Geophys. Res. Atmos. 126 (22), e2020JD034413. doi:10.1029/2020JD034413

Zhu, D. C., Wang, Q., Cawood, P. A., Zhao, Z. D., and Mo, X. X. (2017). Raising the Gangdese Mountains in Southern Tibet. J. Geophys. Res. Solid Earth 122 (1), 214-223. doi:10.1002/2016JB013508

Zhu, C., Meng, J., Hu, Y., Wang, C., and Zhang, J. (2019). East-Central Asian Climate Evolved with the Northward Migration of the High ProtoTibetan Plateau. Geophys. Res. Lett. 46 (14), 8397-8406. doi:10.1029/ $2019 \mathrm{~g} 1082703$
Conflict of Interest: The authors declare that the research was conducted in the absence of any commercial or financial relationships that could be construed as a potential conflict of interest.

Publisher's Note: All claims expressed in this article are solely those of the authors and do not necessarily represent those of their affiliated organizations, or those of the publisher, the editors and the reviewers. Any product that may be evaluated in this article, or claim that may be made by its manufacturer, is not guaranteed or endorsed by the publisher.

Copyright $\odot 2021$ Zhang, Liu, Fang, Zhang, Zhu and Wang. This is an open-access article distributed under the terms of the Creative Commons Attribution License (CC $B Y)$. The use, distribution or reproduction in other forums is permitted, provided the original author(s) and the copyright owner(s) are credited and that the original publication in this journal is cited, in accordance with accepted academic practice. No use, distribution or reproduction is permitted which does not comply with these terms. 